\title{
Worked Example as a Scaffolding on Problem Posing Instruction of Parallel Lines and Transversal Learning
}

\author{
Ibrohim A. Kusuma ${ }^{1, *}$ Endah Retnowati ${ }^{2}$ \\ ${ }^{1}$ Program Pascasarjana, Universitas Negeri Yogyakarta \\ ${ }^{2}$ Program Studi Pendidikan Matematika, Universitas Negeri Yogyakarta \\ *Corresponding author. Email: ibrohimaji.2018@student.uny.ac.id
}

\begin{abstract}
This study aims to review on literature of worked example function as a scaffolding on problem posing instruction, its design and instructional implications. Students should be facilitated to pose problem by relating their existed knowledge to the given information and develop their thinking further. Accordingly, problem posing as an instructional strategy aims to encourage students to generate or pose problems from the given situational information or contexts. Student should not only generate problems, but also, they have to solve the problems they made. The more complex problems that are created and solved could improve their thinking and reasoning abilities. Novice students may experience difficulty as problem posing and solving activity are strongly influenced by the presentation of information and the prior knowledge of students. In this condition, novice might need to use worked examples as context or situational information on problem posing based learning. Students can borrow and apply knowledge from worked examples to pose and solve problems effectively and efficiently. In other side, geometry topic of parallel lines and transversal could be difficult and more challenging for students as it required a lot of principles or theorems to solve at a moment. Therefore, design of problem posing instruction using worked example as a context or situation and its learning procedure on parallel lines and transversal are discussed.
\end{abstract}

Keywords: Worked example, Problem posing, Parallel lines and transversal.

\section{INTRODUCTION}

In order to develop students' thinking abilities, learning should not only ask students to solve problems from the external resources (teachers and textbooks), but also students must be involved in the activities of creating their own problems [1]. According to Silver, Mamona, Leung and Kenny [2], the activity of generating problems can increase student motivation as they feel more excited (challenged) when solving those problems rather than solving problems from external sources.

When generating new problems, students need to associate their existed knowledge to the given information [3]. Existed knowledge refers to the information that they have learned, especially prerequisite knowledge relating to the material being studied. Meanwhile, the given information can be in the form of context or situation that is free, unstructured or structured [4]. Students with fewer prerequisite knowledge may experience difficulty in posing problems because they are not able to associate the given information to their existed knowledge. Conversely, students may pose problems easily if they have sufficient prerequisite knowledge because they are able to associate their existed knowledge to the given information. In addition, students' problem posing activities also requires students' creative thinking abilities [5]-[7]. Therefore, more knowledgeable students tend to be able to pose better problems than novices [8], [9].

Based on level of problem difficulty perspective, students tend to pose problems from simple to complex levels of problems. When students pose higher level of difficult problem, it indicates that they have developed and constructed their knowledge and increased their thinking abilities gradually. For instance, when we give students an information about corresponding angle theorem. Initially, they tend to pose problems associate with or can be solved using corresponding angle theorem only. In other word, students may pose only simple problems because they only use one specific theorem.

Furthermore, when student pose more complex problem, it means that they have related more principle and theorems. The number of theorems involved in 
generating problems are directly proportional to the increasement of difficulty level of the problem. In this condition, students have associated a lot of existed knowledge (theorems that have been learned) to the given information. As a result, he can pose more complex problems and involve higher order thinking abilities. In conclusion, students' thinking abilities improved. As supported by NCTM [1] that students' activities in posing their own problems can develop their thinking abilities further.

\subsection{Problem Posing}

Problem posing is an instructional design that facilitate students to pose problems [2], [10]. Problem posing could be an activity to pose new solvable problems based on given information (pre-solution posing), create an equivalent or more difficult problem from existed problem goal by manipulating the constrains and conditions (within-solution posing). In addition, problem posing could also be an activity to pose problem which related to the solution of the previous problem (post-solution posing) [2], [10], [11].

The presentation of context or situational information is a key point on problem posing instruction. The given context or situational information is the basis of students to pose or generate problems. A good context and situation can stimulate students to activate more existing knowledge [3]. Simultaneously, students activate their knowledge in long-term memory and manage it with the given context or situational information in working memory.

Students might pose two types of problem: symmetrical dan chained problem [2]. Symetrical problem are typically a similar question with existed or previously posed problem. Students could develop symmetrical problem by changing existing problem's goal and conditions. Besides, chained problem is likely a more advanced problem which related to the previous problem. It is characterized as the solution of chained problems requires the solution of previous problem. Kapur [3] argued that symmetrical problem could develop students' concept understanding, whereas chained problem could foster transfer skill. Sample of symetrical and chained problem were shown in Figure 1.

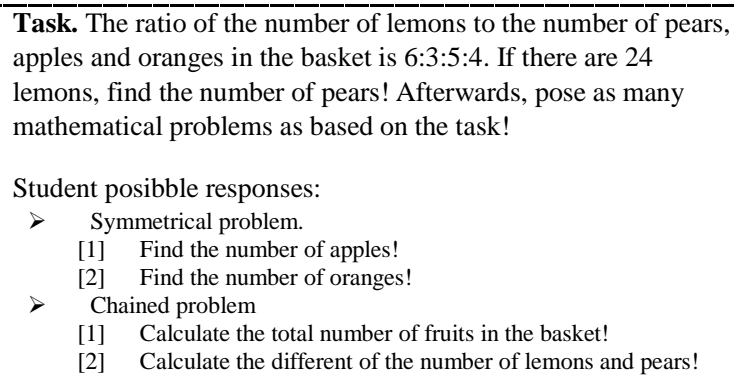

Figure 1 Sampel of symmetrical and chained problem
Many studies confimed that problem posing can influence student's knowledge and skills. Problem posing can increase students conceptual understanding [12], [13], creativity [6], [7], transfer [3] and problem solving skills [6], [14]-[16]. Besides, problem posing can also be used to investigate the student's conceptual understanding and reasoning ability [17]. Moreover, problem posing is not only used in mathematics, but also in different area of subject-domain such as physics [17], [18] and chemistry [19].

\subsection{Problem Solving}

After posing activity, students are also need to solve their own problem as problem solving is the core of mathematics learning [1]. Jonassen [20] argued that problem solving is a prominent aspect on daily lifes and professional. Problem solving can be defined as an activity to find the solutions of problems that can not be directly determine [21]. Polya [22] suggested four steps of problem-solving activity: understanding the problem, planning the procedure to solution, apply the procedure and checking the result. Activity of relating the given situational information and generating problem can be categorized as 'understading the problem' activity.

Problem solving activities are closely related to prior knowledge of students. Inadequate prior knowledge can affect negatively on problem solving activities during learning [23], [24]. With the limitation of prior knowledge, novice students need to be facilitated by scaffolding to overcome learning difficulties that might occur. Scaffolding can be guidance or hint for students when solving problems.

\subsection{Worked Example}

Worked example could be a scaffolding for facilitating students learning. Worked example is an instructional design where students study from examples with systematic hints and steps [25]. Worked exampel consists of problem state or task, procedures and solution [26]. Worked example is one of several learning designs that takes into consideration of students' structure and cognitive functions as working examples can reduce students' cognitive load during learning [25].

Worked example is appropriate for students with inadequate prerequisite knowledge [24]. Students can borrow the information that provided by worked examples to build initial knowledge that can be used to solve problems [27]. After solving the problem, students can construct their own knowledge by relating the information that has just been learned with the knowledge they have [24].

In problem posing, students' lack of prior knowledge may be overcome if the context and the situation are presented in worked examples. Students can generate 
problems by borrowing the information provided by worked example. Students can pose problems that are equivalent to worked examples and use the information from worked example to solve the problems they make. Worked examples also provide solution procedure, thus students can solve problems effectively and efficiently. The more complex problems that are created and solved could improve their thinking and reasoning abilities.

\subsection{Parallel Lines and Transversal}

Parallel lines and transversal was chosen because it is difficult and challenging material for students. When solving parallel lines and transversal tasks, students required a lot of principles or theorems simultaneously. The description of theorems of parallel lines and transversal material are shown on Table 1.

\section{RESULT AND DISCUSSION}

\subsection{Learning Schemas}

Learning on problem posing must be a meaningful learning. Meaningful learning can be defined as a series of learning activities that facilitate students in relating their existed knowledge to the targeted material [28]. Those interrelated knowledges are stored in long term memory in the form of a schema [29], [30]. Hence, teacher has an essential role to facilitate student to experience meaningful learning that is, they develop their thinking by creating schemas or connections between their existed knowledge and targeted material. Therefore, prior knowledge is an important aspect on learning process. Level of prior knowledge could determine the learning outcomes. A low level of prior knowledge

Table 1. Description of theorems of parallel lines and transversal

\begin{tabular}{|l|l|}
\hline Theorems & Description \\
\hline Supplementary angles & The sum of supplementary angles is $180^{\circ}$ \\
\hline Angle at a point & The sum of angles at a point is $360^{\circ}$. \\
\hline Vertically opposite angles & A pair of vertically opposite angles are equal. \\
\hline Corresponding angles & A pair of corresponding angles are equal. \\
\hline Alternate interior angles & A pair of alternate interior angles are equal. \\
\hline Alternate exterior angles & A pair of alternate exterior angles are equal. \\
\hline Consecutive interior angles & The sum of consecutive interior angles is $180^{\circ}$. \\
\hline
\end{tabular}

\section{METHOD}

In this section, we provide eight situated information in the form of worked examples. Situated information was developed referring to theorems of parallel lines and transverse topics. Situated information is used as a basis for students in posing problems. Students can pose as many possible mathematics problems as based on that situated information. In addition, students are also asked to determine the solutions of the problems. Example of problem posing on alternate interior angles was shown on Figure 2.

Worked example. Given that $\mathrm{AB} / / \mathrm{CD}$, find the value of $\angle A E C$ !

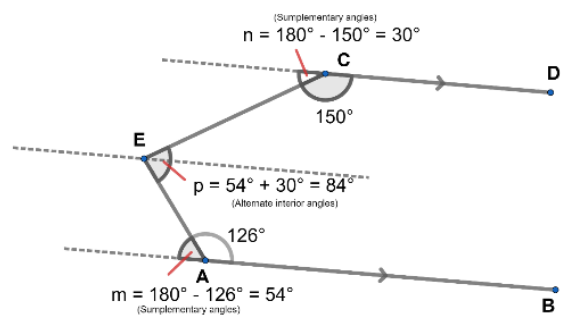

Posing Instruction. Based on information above, create as many new possible mathematics problems and its solutions as you can! imposes learning difficulties for students in constructing schema. Conversely, adequate prior knowledge is required during learning.

At least, students will learn eight theorems on parallel lines and transversal. The teacher should identify the prerequisite material and students need to master those prerequisite material before starting to study parallel lines and transverse topics which affect learning. Learning schema of parallel lines and transversal shown on Tabel 2.

\subsection{Problem Posing Implementation}

Implementation of learning needs to consider several aspects such as the characteristics of students, learning materials and learning instruction. There are three learning parts that may be applied in classroom using problem posing: introductory, acquisition and test.

Introductory part aims to prepare students physically and cognitively before starting learning so that learning can run effectively and efficiently. The teacher also needs to motivate students by explaining the learning purpose. In addition, the teacher needs to activate the prior knowledge of students by providing stimulus about the preprequiste material such as using quizzes, explanations

Figure 2 Problem posing on alternate interior angles 
Table 2. Learning schema of parallel lines and transversal

\begin{tabular}{|l|l|}
\hline Prerequisite material & Initial material \\
\hline Intersecting lines & Suplementary angles \\
\hline Parallel lines & Angle at a point \\
\hline Concept of angle & Vertically opposite angles \\
\hline Angle of perpendicular lines & Corresponding angles \\
\hline Angle sum on a straight line & Alternate interior angles \\
\hline Sum of interior angle of a triangle & Alternate exterior angles \\
\hline Exterior angle of a triangle & Consecutive interior angles \\
\hline Sum of interior angles of a polygon & Consecutive exterior angles \\
\hline
\end{tabular}

and direct question to students. After that, the teacher needs to provide an initial overview of parallel lines and transversal material. Students need to be informed about learning activities such as what they will do using problem posing.

The acquisition part aims to facilitate students studying parallel lines and transversal material. Students are presented with learning instruction that use problem posing. The teacher's role is to help students with the learning activities they are facing. This learning activity is expected to facilitate students in constructing their knowledge related to parallel lines and transversal and to improve their thinking skills. At the end of this stage, students need to present their work in front of the class. It aims to provide feedback and give appreciation to students for the results of their work. The teacher also needs to correct the students' misconception and errors. Finally, the teacher needs to guide students to create conclusions of their learning.

Test part aims to measure the extent of student success in learning. Test items must be able to represent the learning indicators and materials. The test results can be used as an evaluation and assessment to improve the learning quality.

\section{CONCLUSION}

Not only solving problems from books or teachers, students need to be facilitated to create their own problems and solve them. In problem posing, students increase their thinking abilities from pose and solve more complex problems. Unfortunately, the activity of posing and solving problems is influenced by the presentation of information and students' prior knowledge. Using worked example as context and situated information in problem posing may overcome this obstacle.

In learning that involves many theorems such as parallel lines and transversal, problem posing and working examples can be combined well. Students can borrow information from worked examples to pose and solve problems. As a result, learning can run effectively and efficiently. Learning procedures that can be implemented consist of introductory, acquisition and test.

\section{ACKNOWLEDGMENTS}

We thank Lembaga Pengelola Dana Pendidikan (Indonesia Endowment Fund for Education) as scholarship sponsor to Ibrohim A. Kusuma. We have no conflicts of interest to disclose.

\section{REFERENCES}

[1] [1] NCTM, 2000 Principles and Standards for School Mathematics 47, 8 .

[2] Silver E A Mamona-Downs J Leung S S and Kenney P A, 1996 Posing mathematical problems: An exploratory study J. Res. Math. Educ. 27, 3 p. 293-309.

[3] Kapur M, 2015 The preparatory effects of problem solving versus problem posing on learning from instruction Learn. Instr. 39 p. 23-31.

[4] Stoyanova E and Ellerton N F, 1996, A framework for research into students' problem posing, in In P. Clarkson (Ed.), Technology in mathematics education, (Melbourne: Mathematics Education Research Group of Australasia), p. 518-525.

[5] Arıkan E E and Ünal H, 2015 An Investigation of Eighth Grade Students' Problem Posing Skills (Turkey Sample) Int. J. Res. Educ. Sci. 1, 1 p. 23 30 .

[6] Silver E A, 1997 Fostering creativity through instruction rich in mathematical problem solving and problem posing ZDM 29, 3 p. 75-80.

[7] Yuan X and Sriraman B, 2011, An Exploratory Study of Relationships between Students' Creativity and Mathematical Problem-Posing Abilities, in Sriraman B., Lee K.H. (eds) The Elements of Creativity and Giftedness in Mathematics. Advances in Creativity and Giftedness, vol 1. SensePublishers, . 
[8] Cai J, 2003 Singaporean students' mathematical thinking in problem solving and problem posing: An exploratory study Int. J. Math. Educ. Sci. Technol. 34, 5 p. 719-737.

[9] Silver E A and Cai J, 1996 An Analysis of Arithmetic Problem Posing by Middle School Students J. Res. Math. Educ. 27, 5 p. 521-539.

[10]Silver E A, Feb. 1994 On Mathematical Problem Posing Learn. Math. 14, 1 p. 19-28.

[11] English L D, 1997 The Development of Fifth-Grade Children's Problem-Posing Abilities Educ. Stud. Math. 34, 3 p. 183-217.

[12] Abramovich S, 2015 Mathematical problem posing as a link between algorithmic thinking and conceptual knowledge Teach. Math. 18, 2 p. 45-60.

[13] Mahendra R Slamet I and Budiyono, 2017 The effect of problem posing and problem solving with realistic mathematics education approach to the conceptual understanding and adaptive reasoning AIP Conf. Proc. 1913.

[14] El Sayed R A-E, 2002 Effectiveness of problem posing strategies on prospective mathematics teachers' problem-solving performance J. Sci. Math. Educ. S.E. Asia XXV, 1 p. 56-69.

[15] Nuraeni Z and Rosyid A, Jan. 2019 Pengaruh Model Pembelajaran Index Card Match (ICM) dengan Problem Posing Berbantuan Software MATLAB terhadap Kemampuan Pemecahan Masalah J. Elem. 5,1 .

[16] Retnowati E Fathoni Y and Chen O, 2018 Mathematics Problem Solving Skill Acquisition: Learning by Problem Posing or by Problem Solving Cakrawala Pendidik. I.

[17] Mestre J P, 2002 Probing adults' conceptual understanding and transfer of learning via problem posing J. Appl. Dev. Psychol. 23, 1 p. 9-50.

[18] Ergün H, 2010 the Effect of Problem Posing on Problem Solving in Introductory 6, 3 p. 1-10.

[19]Iriani R and Hidayah N, 2017 The Effect of Problem Posing and Problem-Solving Model on Chemistry Learning Outcome Adv. Soc. Sci. Educ. Humanit. Res. 100 p. 87-90.

[20] Jonassen D H, 1997 Instructional design models for well-structured and III-structured problem-solving learning outcomes Educ. Technol. Res. Dev. 45, 1 p. 65-94.

[21] Liljedahl P, 2008 The AHA! experience: Mathematical contexts, pedagogical implications Saarbrücken, Germany: VDM Verlag.
[22] Polya G, 1973 How To Solve It: A New Aspect of Mathematical Method Princeton, New Jersey: Princeton University Press.

[23] Liljedahl P, 2016, Creative problem solving, in Problem Solving in Mathematics Education, ICME13 To, (Springer Nature), p. 6-18.

[24]Retnowati E Ayres P and Sweller J, 2018 Collaborative learning effects when students have complete or incomplete knowledge Appl. Cogn. Psychol.

[25]Sweller J Ayres P and Kalyuga S, 2011 Cognitive Load Theory New York, NY: Springer New York.

[26] Mayer R E, 1999 The promise of educational psychology: Learning in the content areas.

[27] Retnowati E and Marissa, 2018 Designing worked examples for learning tangent lines to circles $\mathrm{J}$. Phys. Conf. Ser. 983, 1.

[28] Ausubel D P, 1963 The psychology of meaningful verbal learning. Oxford, England: Grune \& Stratton.

[29]Schunk D H, 2012 Learning Theories, an Educational Perspective 6th editio Boston, MA: Pearson Education Inc.

[30]Sweller J Van Merrienboer J J G and Paas F, 1998, Cognitive Architecture and Instructional Design. 